\title{
Bridging the gap: exploring police-media relations in Malaysia
}

\begin{abstract}
The Malaysian police and media have had a very volatile relationship. Both are similar, that is responsible to address community issues, crime and crime prevention, yet different as in their perceptions on each other. Through qualitative interviews with Polis Diraja Malaysia (The Royal Malaysian Police) and reporters, this study explored the dynamics of the policemedia relations. In particular, the researchers were able to unveil perceptions of both police and the media on each other, the strategies used by the police in dealing and building the relationship with the media and also factors influencing the relationships. In general, the findings collected from this study suggest that there was no explicit difference in media relations practised by the police from the conventional media relations practice in the corporate world. Findings from our study illustrate that, from the crime reporters' points of views, the police (also played a role as public relations practitioner/media relations specialist) essentially did not understand the needs and demands of journalism. We found that the police had a good relationship with the media at all times; this was rather different from the viewpoint of the media on the police. Our findings of this study attested to the fact that PDRM acted as a media agenda builder.
\end{abstract}

Keyword: Media relations; Police-media relations; Dynamics; Police; PDRM 